подальших розвідок є пошук ефективних форм, методів і засобів попередження синдрому емоційного вигорання майбутніх психологів на етапі підготовки до професійної діяльності.

Ключові слова: психолог, емоційне вигорання, професійна діяльність, механізми психологічного захисту, індивідуально-психологічні особливості.

Submitted on February, 6, 2017

Reviewed by Doctor of Psychology, prof. O. Safin

UDC: 159.922 .762

DOI: https://doi.org/10.24195/2414-4665-2017-3-6

Nataliia Sieromakha,

PhD (Candidate of Psychological Sciences), associate professor, Department of Defectology and Psychological Correction,

Luhansk Taras Shevchenko National University,

1, Gogolia Square, Starobilsk, Ukraine

\title{
STUDYING THE FEATURES OF MENTALLY RETARDED ADOLESCENTS' NONVERBAL BEHAVIOUR
}

The paper is focused on the psychological essence of the concept "nonverbal behaviour"; its components have been specified, namely: understanding other people's nonverbal behaviour, the ability to correlate nonverbal characteristics corresponding to a certain emotional state; the level of verbal communication development, social experience in the process of assessing other people's behaviour according to the standards determined by moral criteria. The programme and the main findings of experimental research of the peculiarities of nonverbal behaviour in mentally retarded adolescents are represented.

Keywords: nonverbal behaviour, behaviour interpretation, the level of awareness, mental retardation, adolescence.

\section{Introduction}

The study of various aspects of behaviour, including features of nonverbal behaviour of mentally retarded children and adolescents, will contribute to the improvement of their social adaptation, search for the ways of correcting social and perceptive processes and behaviour in actual situations of interaction. Mentally retarded adolescents experience difficulties in interpersonal communication. It is difficult for them to understand other people's feelings clearly; their abilities to understand basic emotional states basing on facial expressions are also poor. It is explained by insufficiently developed skills of understanding nonverbal behaviour and organisation of their own nonverbal communication, which are formed much more slowly in mentally retarded adolescents. Therefore, this problem requires psychopedagogical investigation.

In the research works by Ch. Darwin, F. Delsarte, D. Efron, A. Sheflen, P. Ekman, nonverbal behaviour is considered as a complex of various body movements. H. Kovalova, V. Labunska, L. Kononovich, H. Mikkin believe that in psychological literature much attention is paid to the structure and elements of nonverbal behaviour, while psychological content of interpreting various types of nonverbal behaviour are underinvestigated.

Review of the research works dedicated to mentally retarded adolescents' behaviours, ways and means of its correction demonstrates detailed investigation of these issues in the works on psychology and pedagogy for special needs by Ye. Albrecht, V. Bondar, O. Bazhukova, I. Bhazhnokova, Yu. Bystrova, L. Vygotsky, S. Horbenko, H. Zapriahaieva, V. Kovalova, K. Lebedynska, M. Matvieieva, Zh. Namazbaieva, V. Kuzmina, M. Pevzner, O. Romanenko, V. Synova, O. Sieverova, H. Sukhareva, O. Khokhlina and others. Some aspects of studying nonverbal behaviour of mentally retarded adolescents were considered in the works of M. Ahavelian, O. Ahavelian, Yu. Mendzherytska, Ye. Breus, N. Cherepkov, L. Korshykov. However, the impact of nonverbal information on perception, regulation and interpretation of mentally retarded adolescents' behaviour remains understudied in psychology for special needs.

The paper aims to study the features of nonverbal behaviour in mentally retarded adolescents.

\section{Discussion}

Nonverbal behaviour as well as behaviour in general is a combination of individual, personal forms of behaviour with the group, socio-cultural ones. L. Korshykova, V. Labunska, D. Matsumoto, N. Cherepkov think that nonverbal behaviour involves all kinds of behaviour demonstrated in the process of communication except for the pronounced words. These nonverbal aspects of behaviour include facial expressions, hand and leg gestures, postural pose, lean and orientation of the body, voice tone and other vocal characteristics (pitch, speech tempo, intonation and 
pauses), distance between interlocutors, touching each other, glances and visual attention. Consequently, nonverbal behaviour involves various movements associated with changeable mental states of a person, his/her attitude to others, or with a certain situation of interaction and communication [3, p. 93].

Nonverbal behaviour may emphasise emotional state of an individual, inform about the content of speech, emphasise certain information in communication process. In V. Labunska's opinion, nonverbal behaviour performs informational, regulatory and emotional functions in communication. Nonverbal signals are multifunctional. Important for the understanding of nonverbal behaviour identification is the feedback mechanism, which allows a person to correct his/her own behaviour on the basis of the goal achieved in the course of interaction with others, changing the methods of influence into the ones that seem to be more effective.

According to the classification of P. Ekman and W. Friesen, there are five categories of nonverbal behaviour: illustrators, manipulators, emblems, regulators, and emotional expressions. Illustrators are the types of movements used by people to emphasise some aspects of their speech. Manipulators are movements that help body adjust to the environment. Emblems are the movements that contain information in themselves. Emotional expressions are messages conveyed by nonverbal behaviour. Regulators are aspects of nonverbal behaviour that regulate speech flow during communication [3, p. 92].

The main ways of understanding nonverbal behaviour involve empathy, reflection, analysis of communicative situations and verbal behaviour of people along with estimation of the state based on the image on nonverbal behaviour. Peculiarities of empathy are manifested in the ability of a person to put him-/herself in another person's place, see others' problems with his/her own eyes, to feel and understand another person's state and behave accordingly. Reflection is the processes of self-cognition of one's own inner psychic acts and state [5, p. 35].

Adolescence is an extremely sensitive age for the acquisition of communicative knowledge and abilities that are being transformed into individual experience by means of gradual interiorisation, and this experience will be used in various spheres of life in future. Adolescents start to scrutinise themselves in the mirror, make faces and use some mimic and pantomimic means. This need for self-cognition is expressed in studying the manifestations of their physical capabilities, their physical "self". The ability to understand oneself and other people in terms of their nonverbal behaviour is of key importance for successful communication. Nonverbal means of behaviour differ by their individual expressions, which makes their reading and interpretation difficult [6, p. 136].

Researchers think that adolescents perceive body language better than adults who have been trying to pay attention to words and ignore body language throughout life. Reading and understanding other people's body language implies that an adolescent is in harmony with his/her own body and feels its expressions, so that his/her image of him-/herself and his/her physical "self" is formed. Therefore, if an adolescent can understand and feel what is expressed by his/her body, he/she can understand the meaning or expression of another person's body (V. Kunitsyna, N. Kazarinova, V. Poholsha) [4, p. 114].

Mentally retarded adolescents appear to be incapable to master the skills of interpersonal communication and enter the sphere of social relations independently (O. Ahavelian, R. Aslaieva, L. Darhevychene, N. Dementieva, M. Moskalenko). They experience difficulties in nonverbal communication associated with disabilities in social perception, behaviour deviations. Also, communication becomes complicated by emotional sphere disorders and immaturity of self-control skills. Inability to express one's feelings properly, restraint, inappropriateness of facial expressions and gestures make communication of mentally retarded adolescents with other people difficult. Sometimes, adolescents of this category cannot communicate verbally, therefore nonverbal means of communication, expressing one's emotions and needs in the form of facial expressions and gestures gain importance [7, p. 135].

The research conducted by V. Viarianien prove that mentally retarded adolescents regularly come across various symbolic information of nonverbal character, the need to familiarise, become acquainted and verbalise sign systems, respond to them properly and use them for recoding information into the system of real behaviour [9, p. 39].

In Ch. Kozhaliiev's opinion, mentally retarded children aged 13-14 experience qualitative change of one of the main ways of understanding nonverbal behaviour change of personal reflection. Their ability to imagine themselves in communication situation, understand the immediate surrounding's (parents, teachers, classmates, friends) view of them is being developed [7, p. 140].

The research of D. Nazambaieva also demonstrates a real opportunity for mentally retarded children to master the elements of nonverbal behaviour. The researchers O. Ahavelian, O. Asmolov, M. Khomelauri, Sh. Nadirashvili, D. Uznadze note that if a mentally retarded adolescent receives preliminary verbal information about the observation object, it will facilitate more precise formation of this object's image [9, p. 43].

M. Haidukevych distinguishes the following levels of nonverbal means that improve mutual understanding in the process of mentally retarded adolescents' communication:

- the level of direct self-expression (body movements, facial expressions);

- the level of direct operations with objects (different types of tactile contacts, operations with things);

- the level of secondary nonverbal means (the use of images, pictograms, gestures, echolalia, demonstrations of problem behaviour);

- the level of verbal and alternative forms of communication (language itself, the use of gestures of finger language and Braille alphabet) $[1$, p. 55]. 
The use of nonverbal means in communication of mentally retarded adolescents will allow them to approve themselves as personalities who are able to respond properly to external social influences that are mostly manifested in communication process.

Experimental research on the peculiarities of understanding nonverbal behaviour by mentally retarded adolescents was conducted at the premises of Teplovske Regional Psychoneurological Boarding School (Luhansk region, Ukraine). 52 mentally retarded adolescents aged from 12 to 16 years were involved in the experimental research.

The following methods were used in the experimental research:

- Methodology for characterising the level of development of the ability for interpreting nonverbal behaviour in interpersonal communication (by V. Labunska). The methodology consists of 8 tasks; each of them is aimed at characterising the level of child's proper understanding of the following: states and relations of people judging from their postural pose and facial expressions; intellectual and volitional states judging from nonverbal behaviour; relations between people belonging to a nonverbal group; elements of nonverbal behaviour; regulation of relationships in the group towards emotionally positive or negative aspect.

- Methodology for assessing behaviour by L. Venher is aimed at revealing social experience in the process of the study participants' evaluation of other people's behaviour according to the standards predefined by moral criteria.

The study participants are offered some ordered pictures of children in different real-life situations, which are understandable and familiar to them. The children committing good deeds are usually ill-dressed, ugly and sometimes dirty. At the same time, the children committing bad deeds are usually well-dressed and pretty. The analysis of adolescents' replies makes it possible to divide them into three groups: the adolescents who find appearance important, the adolescents who do not have any preferences in evaluating the characters' behaviour, the adolescents with the high level of social normativity.

- Methodology for building a nonverbal profile (by L. Subotina), which makes it possible to evaluate the ability to correlate certain nonverbal signs (eyes, lips, hands, arms) creating the dynamic peculiarities of one's image corresponding to the certain emotional state. The study participants are offered a number of pictures of expressive elements of facial expressions and gestures. Each of them expresses certain feeling. The test conductor asks the adolescents to create the prettiest and the ugliest person using the elements. After that, emotional and feeling profile is prepared on the basis of the chosen elements. The adolescents then asked to explain their choice of the elements. The latter are correlated with personal qualities represented in the answer key.

- Methodology for expert evaluation of nonverbal behaviour (by A. Kuznetova), which identifies the level of the adolescents' nonverbal communication development (in this case, the respondents are special education teachers). The methodology provides the diagnosing of three parameters of nonverbal behaviour: overall assessment of adolescents' nonverbal repertoire; sensitivity to other people's nonverbal behaviour; the ability to manage one's nonverbal repertoire proceeding from the aim and situation of communication.

When analysing the methodology for diagnosing the level of development of mentally retarded adolescents' ability for interpreting nonverbal behaviour in interpersonal communication, two aspects were taken into account: the ability to understand various forms of nonverbal behaviour and to regulate relationships in different social contexts with the help of nonverbal expression of emotions. According to the results of the methodology, the following features of understanding nonverbal behaviour by mentally retarded adolescents have been revealed: the study participants do not indicate the psychological meaning of postural pose directly, they only specify the situation, in which this pose may be appropriate (the task "Poses"); they indicate only emotional state of the character without specifying emotional connotations of this state (the task "Facial expressions gestures"); they cannot estimate people's emotional states according to facial expressions (the task "Facial expressions").

Mentally retarded adolescents demonstrate the low level of the ability for proper interpretation of relations between people (the task "Postural pose - face"), average level of the ability to regulate relations towards emotionally negative or positive side (the task "Harmony"); the low level of the ability to establish proper relations between verbal and nonverbal behaviour of people (the task "Facial expressions - reply"). The mean value of all the tasks of the methodology is 60 points, which indicates that the level of proper understanding of nonverbal behaviour by mentally retarded adolescents was below the average.

Analysis of the methodology for assessing behaviour has made it possible to observe social experience based on the ability to evaluate behaviour according to the standards determined by moral criteria.

It has been found that the adolescents belonging to the first group ( $31 \%$ of the study participants) assess characters' behaviour relying on their appearance; they do not understand the characters' inner emotions and latent meaning of the situation (the low level of social normativity). Therefore, the adolescents judge the characters of the methodology only by appearance, their own liking or dislike.

The adolescents from the second group (69\% of the study participants) are those who do not have any preferences in assessing the characters' behaviour. The answers involve assessment of the characters' behaviour, while it is emphasised that their appearance does not correspond to commonly accepted norms. However, the adolescents tried to explain the characters' appearance. 
None of the adolescents demonstrated the high level of social normativity.

When interpreting the methodology for building a nonverbal profile we have found that mentally retarded adolescents are mostly characterised by the low level of certain images-criteria formation. The study participants have more or less formed criteria of the states demonstrating joy, happiness, sadness, anger, and fear. However, the low level of the ability to correlate nonverbal characteristics of certain emotional states with each other dominates. $36 \%$ of the adolescents demonstrated the average level of the ability to correlate nonverbal characteristics (the study participants coped with the task incompletely: they could identify nonverbal characteristics according to two categories only); $58 \%$ of the adolescents demonstrated the low level of the ability to correlate nonverbal characteristics (the study participants could identify nonverbal characteristics only in one category, it was difficult for them to explain their choice); $6 \%$ of mentally retarded adolescents had the high level (the adolescents managed to do the task and identified several nonverbal characteristics according to three categories correctly).

The analysis of the findings obtained by means of the methodology of expert evaluation of nonverbal communication between mentally retarded adolescents has shown that mentally retarded adolescents' sensitivity to other people's nonverbal behaviour, their ability for its proper identification is at the average level ( 15 points of 28 possible). The study participants have the low level of the ability to regulate their nonverbal behaviour in a communicative situation (10 points of 23). Overall assessment of mentally retarded adolescents' nonverbal

\section{REFERENCES}

1. Agavelyan, O. K. (1999). Sotsialno-pertseptivnye osobennosti detei $s$ narusheniiami razvitiia [Socially perceptive features of children with developmental disabilities]. Cheliabinsk: ChTU [in Russian].

2. Gorelov, I. N. (2009). Neverbalnye komponenty kommunikatsii [Nonverbal components of communication]. Moscow: Knizhnyi dom "LIBROKOM" [in Russian].

3. Kostin, D. V. (2009). Issledovanie neverbalnogo komponenta obscheniya u detey s retardatsionnym tipom dizontogeneza [The study of nonverbal communication of mentally retarded children]. Sovremennye naukoemkie tekhnologii - Contemporary science-based technology. (pp. 89-106). Moscow [in Russian].

4. Krutetskiy, V. A., \& Lukin, N. S. (1965). Psikhologiya podrostka [Adolescent psychology]. Moscow: Prosveschenie [in Russian].

5. Labunskaya, V. A. (1991). Neverbalnoe povedenie [Nonverbal behaviour]. Moscow: Prosveschenie [in Russian].

6. Labunskaya, V. A. (1999). Usloviya opoznaniya emotsionalnykh sostoianiy po vyrazheniyu litsa behaviour in terms of its diversity, consistency and differentiation equals to 4 points out of 9 . It indicates the low level of mentally retarded adolescents' nonverbal behaviour formation.

\section{Conclusions}

We can conclude that nonverbal behaviour is the individual, specific sensory form of actions and deeds conveyed by an individual with the help of nonverbal means of communication. The main means of understanding nonverbal behaviour by mentally retarded adolescents are empathy, reflection, analysis of communicative situation and people's behaviour in the process of communication. Mentally retarded adolescents experience difficulties in communication associated with behaviour deviations, emotional disturbances and lack of self-control skills.

According to the results of the experimental research on the peculiarities of mentally retarded adolescents' nonverbal behaviour, their level of proper understanding of other people's nonverbal behaviour is below average. Most adolescents of this category have the low $(58 \%$ of the study participants) and average (36\%) level of formation of nonverbal behaviour images-criteria. It has been found that $67 \%$ of mentally retarded adolescents have the low level of the ability to correlate nonverbal characteristics corresponding to a certain emotional state with each other. Therefore, they experience difficulties in understanding other people's nonverbal behaviour and in organising their own nonverbal communication. Further study should be aimed at investigating the issues of organising correction of the development of mentally retarded adolescents' nonverbal behaviour in communicative situations.

[Conditions for recognising emotional states according to facial expressions]. Teoreticheskie i prikladnye problemy psikhologii poznaniya lyudmi drug druga - Theoretical and applied aspects of psychology of people's knowing each other. (pp. 52-63). Moscow [in Russian].

7. Synov, V. M., Matvieieva, M. P., \& Khokhlina, O. P. (2008). Psykholohiia rozumovo vidstaloi dytyny [Psychology of mentally retarded children]. Kyiv: Znannia [in Ukrainian].

8. Cherepkova, N. V. \& Korshikova, L. V. (2013). Issledovanie neverbalnykh komponentov obscheniya u uchaschikhsya $\mathrm{s}$ narusheniem intellekta [The study of nonverbal components of communication between mentally retarded students]. Kavkazskiy federalnyi universitet - Caucasus federal university. (pp. 82-89). Stavropol [in Russian].

9. Shipitsyna, L. M., \& Zaschirinskaya, O. V. (2009). Neverbalnoe obschenie u detey pri normalnom $i$ narushennom intellekte [Nonverbal communication between mentally retarded and mentally healthy children]. St. Petersburg: Rech [in Russian]. 


\section{ЛІТЕРАТУРА}

1. Агавелян О. К. Социально-перцептивные особенности детей с нарушениями развития / О. К. Агавелян. - Челябинск : ЧТУ, 1999. - 358 с.

2. Горелов И. Н. Невербальные компоненты коммуникации / И. Н. Горелов. - М. : Книжный дом «ЛИБРОКОМ», 2009. - $112 \mathrm{c}$.

3. Костин Д. В. Исследование невербального компонента общения у детей с ретардационным типом дизонтогенеза / Д. В. Костин // Журнал «Современные наукоемкие технологии». - М., 2009. C. $89-106$.

4. Крутецкий В. А. Психология подростка / В. А. Крутецкий, Н. С. Лукин. - М. : Просвещение, 1965. $316 \mathrm{c}$.

5. Лабунская В. А. Невербальное поведение / В. А. Лабунская. - М. : Просвещение, 1991. - 109 с.
6. Лабунская В. А. Условия опознания эмоциональных состояний по выражению лица / В. А. Лабунская // Теоретические и прикладные проблемы психологии познания людьми друг друга. - М., 1999. - C. 52-63.

7. Синьов В. М. Психологія розумово відсталої дитини : підручник / В. М. Синьов, М. П. Матвєєва, О. П. Хохліна. - К. : Знання, 2008. - 359 с.

8. Черепкова Н. В. Исследование невербальных компонентов общения у учащихся с нарушением интеллекта / Н. В Черепкова, Л. В. Коршикова // Кавказский федеральный университет. - Ставрополь, 2013. - С. 82-89.

9. Шипицына Л. М. Невербальное общение у детей при нормальном и нарушенном интеллекте. Монография / Л. М. Шипицына, О. В. Защиринская. СПб : Речь, 2009. - 128 с.

Наталія Свгенівна Серомаха, кандидат психологічних наук, доцент кафедри дефектології та психологічної корекиії, Луганський національний університет імені Тараса Шевченка, пл. Гоголя 1, м. Старобільск, Україна

\section{ДОСЛІДЖЕННЯ ОСОБЛИВОСТЕЙ НЕВЕРБАЛЬНОӤ \\ ПОВЕДІНКИ РОЗУМОВО ВІДСТАЛИХ ПІДЛІТКІВ}

Статтю присвячена вивченню деяких аспектів невербальної поведінки розумово відсталих підлітків. Останні відчувають труднощі у міжособистісному спілкуванні, оскільки нечітко розуміють почуття оточуючих людей. Це пов'язується з недостатнім володінням навичками розуміння невербальної поведінки та організації власної невербальної комунікації, які у підлітків зазначеної категорії формуються з великим запізненням. Дослідження різних аспектів поведінки, зокрема особливостей невербальної поведінки розумово відсталих дітей і підлітків, є актуальним, оскільки сприятиме поліпшенню їхньої соціальної адаптації, пошуку шляхів корекції соціально-перцептивних процесів і поведінки в реальних ситуаціях взаємодії. В експерименті взяли участь 52 підлітка віком від 12 до 16 років із розумовою відсталістю. Було застосовано такі методики: методика діагностики рівня розвитку здатності до інтерпретації невербальної поведінки у міжособистісному спілкуванні; методика «Оціни поведінку», спрямована на виявлення соціальних переживань в процесі оцінки досліджуваними поведінки інших людей по заданих моральними критеріями нормах; методика «Складання невербального портрета», яка дозволяє виявити вміння співвідносити окремі невербальні ознаки між собою, створювати в комплексі динамічні особливості образу, що відповідає певному емоційному станові; методика експертної оцінки невербальної комунікації, яка визначає рівень розвитку невербальної комунікації учнів (респондентами виступають корекційні педагоги). Практичне дослідження особливостей невербальної поведінки розумово відсталих підлітків показало, що рівень адекватності розуміння невербальної поведінки досліджуваними нижче середнього. У більшості підлітків цієї категорії переважає низький (58\% досліджуваних) і середній (36\%) рівень сформованості образів-еталонів невербальної поведінки. Виявлено, що у 67\% розумово відсталих підлітків переважає низький рівень вміння співвіднесення окремих невербальних ознак, що відповідають певному емоційному станові, між собою. Отже, у підлітків із розумовою відсталістю існують труднощі в розумінні невербальної поведінки інших людей, а також в організації власної невербальної комунікації, проте ця категорія підлітків має реальну можливість оволодіння вміннями інтерпретації поведінки інших та користування невербальними засобами спілкування.

Ключові слова: невербальна поведінка, інтерпретація поведінки, ступінь усвідомленості, розумова відсталість, підлітковий вік.

Reviewed by Doctor of Psychology, prof. Yu. Bystrova 